\title{
Employment, Knowledge and Latrine Ownership as Risk Factors and Prediction Model of Diarrhea Incidence
}

\author{
Irfan, Sulansi \\ Health Polytechnic MoH Kupang, NTT Province, Indonesia
}

\begin{abstract}
Article Info
Article history:

Received Jan 27, 2016

Revised Mar 20, 2016

Accepted May 10, 2016

\section{Keyword:}

Diarrhea

Employment

Knowledge

Latrine Ownership

ABSTRACT

Diarrhea is a leading cause of death ranked $3^{\text {rd }}$ after Tuberculosis and Pneumonia in Indonesia. Diarrhea cases in NTT province and also in Kupang City is still high, with Pasir Panjang PHC in 2012 and 2013 ranked the top three, while Oepoi PHC always the lowest rank. This research was conducted to analyze the risk factors for the incidence of diarrhea and create a model equation to predict the diarrhea incidence. This observational analytic research using case control design. Samples with diarrhea cases were recorded in January - June 2015 in the register book Pasir Panjang PHC and Oepoi PHC taken by random sampling to obtain samples for cases 62 children of Diarrhea patient. The control samples are 62 children who are not registered as suffering from diarrhea in the month of June 2015, close to the patient's house, and her mother or people who responsible to care those children want as respondent. Data were obtained by interviews with the mothers of cases and controls using questionnaires and direct observation using a checklist. Data were analyzed using univariate, bivariate and multivariate logistic regression. There are three variables that significantly affect to the diarrhea incidence, namely employment, knowledge and latrine ownership and the most dominant variable influence that is knowledge (OR 4.353). The model equation $\mathrm{Y}=-2.048+1.153$ employment +1.483 knowledge +1.480 latrine ownership with a percentage accuracy of the model in classifying observations is $68.5 \%$.
\end{abstract}

Copyright (C) 2016 Institute of Advanced Engineering and Science. All rights reserved.

\section{Corresponding Author:}

Irfan Irfan,

Health Polytechnic MoH Kupang,

NTT Province, Indonesia.

Email: uma1971kupang@gmail.com

\section{INTRODUCTION}

Diarrhea is still a global problem, especially for developing countries and cause death, especially in children less than 5 years as many as $76 \%$ of deaths due to diarrhea [1]-[3]. As many as 10\% of children with diarrhea will dehydrate and $0.5 \%$ will die [2] and about $25 \%$ of the difference in growth disorders in children in developing countries and developed countries can be attributed due to diarrhea [2]

Diarrhea and other gastroenteritis ranked first in patients in hospitals in Indonesia 2008 is $8.23 \%$. Diarrhoea is a leading cause of death ranked 3rd because of infectious disease after tuberculosis (TB) and pneumonia [4]. Incredible incident of Diarrhea always occur each year in Indonesia with a Case Fatality Rate (CFR), which is still high [4] Based on Basic Health Research 2013, although the number of cases of diarrhea outbreak in 2013 was down compared to the year 2012, from 1,654 cases in 2012 to 646 cases in 2013, but the CFR because of outbreaks of diarrhea is still higher than the national target or still more than $1 \%$ [1]

Likewise, morbidity and mortality of Diarrhea are still high in NTT Province and had the 5th highest incidence of diarrhea nationally 2007 [5]. While based on his diagnosis in 2013 overall NTT IR ranked 17th with $2.6 \%$, while the toddler was $4.6 \%$ [1] Diarrheal diseases could potentially cause outbreaks in NTT 
Province, where the second highest frequency after DHF. NTT was ranked second highest period prevalence of diarrhea (10.9\%) in 2013 after Papua (14.7\%), and is higher than the national average (7\%) [1].

Diarrhea is an endemic disease in NTT Province and also in Kupang City. Diarrhea cases in Kupang City in 2012 and 2013 fell compared to 2011, but diarrheal diseases remain among the top 10 of Disease [6][8]. Based on the incidence rate of Diarrhea, Diarrhea in Pasir Panjang PHC in 2012 and 2013 was ranked the top three, while in Oepoi PHC always the lowest rank, as shown in Table 1.

Table 1. Incidence Rate (IR) of Diarrhea per 100,000 Population by Public Health Centers in Kupang City

\begin{tabular}{cccc}
\hline Subdistrict & PHC & IR 2012 & IR 2013 \\
\hline \multirow{2}{*}{ Alak } & Naioni & 38.71 & 31.04 \\
& Alak & 30.56 & 29.06 \\
Maulafa & Sikumana & 16.76 & 18.67 \\
Kota Raja & Penfui & 36.39 & 43.59 \\
Oebobo & Bakunase & 22.45 & 19.81 \\
& Oebobo & 13.59 & 15.21 \\
Kota Lama & Oepoi & 6.31 & 7.57 \\
Kelapa Lima & Pasir Panjang & 44.59 & 43.01 \\
& Kupang Kota & 27.24 & 28.28 \\
\hline
\end{tabular}

Prevention Diarrhea can be done for example by breastfeeding and correct complementary feeding, the use of clean water, washing hands before preparing food, defecation in latrine, dispose of feces baby in the toilet and immunization against measles [9]. Prevention of Diarrhea would be more effective if done by the government together with the community and stakeholders and if based on the knowledge of the risk factors of diarrhea in a region. This research was conducted to analyze the risk factor for the incidence of diarrhea and create a model equation to predict the incidence of diarrhea in Kupang City.

\section{RESEARCH METHOD}

This observational analytic research using case control study design. Research starting from cases and controls then be back to see their risk factors. The population is all patients of Diarrhea in Pasir Panjang PHC (high IR) and Oepoi PHC (low IR) of Kupang City. Samples with diarrhea cases were recorded in January - June 2015 in the register book as many as 31 cases of health centers in Pasir Panjang health centers and 31 cases in PHC Oepoi taken by random sampling. Control samples are not listed as a child with diarrhea in the month January - June 2015, their house close to the cases's house, and mother or people who responsible to take care children want to be a respondent, ie 31 people in Pasir Panjang PHC and 31 people in Oepoi PHC.

The dependent variable was the incidence of diarrhea and independent variables are education, employment, knowledge, attitude, behavior, latrine ownership and condition of latrine. Interviews were conducted to respondents using questionnaires and direct observation to their house physical condition using checklists. The data obtained was processed descriptively to describe the frequency distribution of the study variables and analyzed using logistic regression multivariate to see the effect of independent variables on the dependent variable.

\section{RESULTS AND ANALYSIS}

\subsection{Results}

This study found that the vast majority of cases and controls already had high school or college, and can be seen completely in Table 2. Table 2 also shows the knowledge and attitudes of respondents mostly unfavorable in the case as well as on the control, whereas preventive action diarrhea respondent had almost the same percentage. The study also found most of the cases and controls have their own latrines with toilet conditions are eligible.Bivariate analysis results can be seen in Table 3, were found four variables value $<0.25$ : education, employment, knowledge and latrine ownership, which means that only four variables that could be included in the multivariate analysis. 
Table 2. Univariate Analysis of Research Variable at Cases and Controls Groups

\begin{tabular}{llcccccc}
\hline & Variable & \multicolumn{2}{c}{ Cases } & \multicolumn{2}{c}{ Controls } & \multicolumn{2}{c}{ Total } \\
& & $\mathbf{n}$ & $\mathbf{9}$ & $\mathbf{n}$ & $\mathbf{\%}$ & \multicolumn{1}{c}{$\mathbf{n}$} & \% \\
\hline Education Level & S Secondary School & 19 & 30.6 & 11 & 17.7 & 30 & 24.2 \\
& High School / College & 43 & 69.4 & 51 & 82.3 & 94 & 75.8 \\
Employment & Housewife/Farmer/Laborer & 39 & 62.9 & 24 & 38.7 & 63 & 50.8 \\
& Civil servant/self-employed & 23 & 37.1 & 38 & 61.3 & 61 & 49.2 \\
Knowledge & Less/Enough & 58 & 93.5 & 47 & 75.8 & 105 & 84.7 \\
& Good & 4 & 6.5 & 15 & 24.2 & 19 & 15.3 \\
Attitude & Negative & 51 & 82.3 & 49 & 79.0 & 100 & 80.6 \\
& Positive & 11 & 17.7 & 13 & 21.0 & 24 & 19.4 \\
Behavior & Less/Enough & 36 & 58.1 & 35 & 56.5 & 71 & 57.3 \\
& Good & 26 & 41.9 & 27 & 43.5 & 51 & 42.7 \\
Latrine & Neighbor/Public & 13 & 21.0 & 4 & 6.5 & 17 & 13.7 \\
Ownership & Private & 49 & 79.0 & 58 & 93.5 & 107 & 86.3 \\
Latrine Condition & Not Sufficient & 26 & 41.9 & 27 & 43.5 & 53 & 42.7 \\
& Sufficient & 36 & 58.1 & 35 & 56.5 & 71 & 57.3 \\
Total & & 62 & 100 & 62 & 100 & 124 & 100 \\
\hline
\end{tabular}

Table 3. Bivariate Analysis of Research Variable at Cases and Controls Groups

\begin{tabular}{|c|c|c|c|c|}
\hline & Variables & P Value & OR & $95 \%$ CI \\
\hline Education Level & $\begin{array}{l}\leq \text { Secondary School } \\
\text { Tertiary School / University }\end{array}$ & 0.092 & 2.049 & $0.879-4.775$ \\
\hline Employment & $\begin{array}{l}\text { Housewife/Former /Laborer } \\
\text { Civil Servant/Self-employed }\end{array}$ & 0.007 & 2.685 & $1.299-5.547$ \\
\hline Knowledge & $\begin{array}{l}\text { Less/Enough } \\
\text { Good }\end{array}$ & 0.005 & 4.628 & $1.439-14.882$ \\
\hline Attitude & $\begin{array}{l}\text { Negative } \\
\text { Positive }\end{array}$ & 0.649 & 1.230 & $0.503-3.006$ \\
\hline Behavior & $\begin{array}{l}\text { Less/Enough } \\
\text { Good }\end{array}$ & 0.856 & 1.068 & $0.524-2.176$ \\
\hline Latrine Ownership & $\begin{array}{l}\text { Neighbor/Public } \\
\text { Private }\end{array}$ & 0.016 & 3.847 & $1.178-12.562$ \\
\hline Latrine Condition & $\begin{array}{l}\text { Not Sufficient } \\
\text { Sufficient }\end{array}$ & 0.856 & 0.936 & $0.460-1.907$ \\
\hline
\end{tabular}

After analyzing by multivariate logistic regression with enter method, this research discovered three variables that significantly affect to the incidence of diarrhea because the p-value $<0.05$, namely employment, knowledge and latrine ownership, as shown in Table 4. The most dominant variable that influence the Diarrhea incidence is knowledge with OR 4.353, with the model equations to predict the incidence of diarrhea: $\mathrm{Y}=-2.048+1.153$ employment +1.480 knowledge +1.483 latrine ownership. The percentage of accuracy in classifying observation models is $68.5 \%$, or 124 observation there are 85 observations precise classification by logistic regression models.

Table 4. Multivariate Analysis of Research Variables at Cases and Controls Groups

\begin{tabular}{lccccccc}
\hline \multicolumn{1}{c}{ Variables in the Equation } & B & S.E. & Wald & Df & Sig & Exp(B) & 95\% CI \\
\hline Employment & 1.153 & .400 & 8.321 & 1 & .004 & 3.167 & $1.447-6.933$ \\
Knowledge & 1.480 & .616 & 5.767 & 1 & .016 & 4.392 & $1.313-14.693$ \\
Latrine Ownership & 1.483 & .647 & 5.258 & 1 & .022 & 4.404 & $1.240-15.639$ \\
Constant & -2.048 & .634 & 10.438 & 1 & .001 & .129 & \\
\hline
\end{tabular}

\subsection{Discussion}

Employment, knowledge and latrine ownership are risk factors of Diarrhea in this research, with the influence of these variables is $68.5 \%$, and knowledge is the most influential variable here. So here there are still $31.5 \%$ influence of other factors outside of employment, knowledge and latrine ownership that affect to the incidence of diarrhea. The percentage of educated less than secondary school in cases and controls groups is lower than the percentage of educated high school / college, but the percentage in the cases $(30.6 \%)$ is 
higher than in controls $(17.7 \%)$. However, multivariate analysis showed education is not a risk factor for diarrhea. Previous research states that maternal education is not associated with the behavior of families in the use latrine [10] so that even if the mother's education is high but they could do defecate not in the toilet, and vice versa although maternal education is low, they can always do defecate in latrines which is one for the prevention of the occurrence of diarrhea, the possibility of which were related because latrine ownership. This means that higher education does not guarantee a person's behavior is healthy. It is different with theory from Notoatmodjo that the level of education will improve health knowledge and it will bring an increase in positive behavior change [11]. According to research by Evayanti et al. conducted in Tabanan also stated there was no association between maternal education with the incidence of diarrhea in children [12].

Employment in this research is risk factor for diarrhea with OR 3.167. It means that mothers who have jobs like housewives, farmers, or workers at risk for the children affected by diarrhea 3.167 times greater than mothers who work self-employed, private employees or civil servants. This is probably because in addition to their education low also at work as housewives, farmers or laborers no information about Diarrhea, while mother worked as a self-employed, private employees and civil servants there is access to get information about Diarrhea in their workplace could eventually increase knowledge about diarrhea and their healthy behaviors.

This study found the majority of mothers have less knowledge about diarrhea either in the cases group and the controls group, but in the cases group less knowledge has a higher percentage than controls group. Results of multivariate analysis turns out there is an influence of mother's knowledge on the incidence of diarrhea with OR 4.392, meaning that children that their mothers have lack the knowledge at risk of suffering from diarrhea 4.392 times greater than the risk of children that their mothers have a good knowledge of diarrhea. It is also the same as in Sragen and Karanganyar research that is based on chi-square test knowledge correlate with the incidence of diarrhea [13],[14].

The importance of the influence of knowledge on the incidence of diarrhea is in contrast with previous studies that did not specify the mother's knowledge in the use of latrines [10]. So the use of latrine as one way of preventing diarrhea is not caused by knowledge but by other factors, namely the attitude of the mother, possession of latrines, clean water facilities, coaching staff and support personnel [10].

Education is guiding people to obtain information that can be used to improve the quality of life. In general, the higher one's education the easier it will receive more and better information and knowledge [15]. But in this study maternal education has no effect on the incidence of diarrhea, because education is measured in this study is a formal education, while a source of knowledge of the mother is not only formal education but could informal example of counseling, from print and electronic media, from friends, or from work(11) as described earlier in this study that the job also affect the incidence of diarrhea.

In this study, the majority already used latrines, but in the percentage of ownership of private latrine in the control group was higher than the cases and after multivariate analysis turns latrine ownership in this study has the OR 4.404, which means they do not have their own latrines then the child at risk Diarrhea is 4.404 times greater than when they have their own latrines. This is possibly related to the use of latrines, people have their own latrines it will be greater use of latrines to defecate either for themselves or their children and the whole family. Statistically role latrine ownership of the use of latrines has also been demonstrated in previous studies with OR 27.03, or those who have latrines will use the toilet for defecate 27.03 times more often than those who do not have their own latrines [10]. Similarly, research in Sukoharjo and Boyolali showed there is a relationship between the incidence of diarrhea with latrine ownership $[16],[17]$ and the percentage of diarrhea was lower in children who live at home with their own latrines [4]. Thus systematic review of research that be done by Adisasmito found that there are five studies that claim latrine ownership statistically significant risk factors for the incidence of diarrhea [18].

Latrines are factors enabling or enabling health behaviors do not defecate in any place in order to prevent the incidence of diarrhea. The toilet is essential that there should be a facility for families not to do open defecation [10] Although the mother's knowledge is good, but if it is not supported by the latrine ownership it will be difficult for family members to do not open defecation [10] and it certainly can contaminate soil and water in the vicinity. Type of latrine that good and fit for health requirements is the type of swan neck so it does not allow animals and odors out through the holes closet because the neck is always filled with water [19].

Research in Bangli found that latrine ownership related to several factors such as economic factors, attitudes, knowledge, attitude and role of health personnel, so here to change the latrine ownership must consider factors related to them, and that change will not happen quickly so that extension or triggers to the community should be repeated with the involvement of relevant sectors [20]. Even though in this study latrine ownership is a risk factor of diarrhea, the condition of latrine is not a risk factor for diarrhea. In contrast, the study in Sukoharjo found an association between the quality of the latrines with the incidence of diarrhea [16] and also by systematic review previously found that there are four studies that the condition of 
latrines as a risk factor for diarrhea and only one study stating latrine condition not as a risk factor for diarrhea [18].

There are still many other factors that affect to the incidence of diarrhea that may be more dominant role than the condition of toilet or latrine ownership, such as the availability of clean water, hygiene of food and beverages as well as the equipment they wear, employment, knowledge of diarrhea, socio-economic and other factors [21]. Breastfeeding is also very influential, [22]-[24] as well as factors unprotected water sources clean, and ownership of animals at home [25],[26]. The age of children and their mother are also predicted as important factors of Diarhhea incidence [18],[27]. It has also been shown in this study that the three significant variables only influence the Diarrhea incidence $68.5 \%$, which means that there are still $31.5 \%$ influence of other factors outside of employment, knowledge and latrine ownership that affect to the incidence of diarrhea.

\section{CONCLUSION}

There are three variables that significantly affect to the incidence of diarrhea that are working, knowledge and latrine ownership. This research obtained the model equation $\mathrm{Y}=-2.048+1.153$ working + 1.483 knowledge +1.480 latrine ownership, with the percentage of accuracy in classifying observation models is $68.5 \%$. The most dominant variable is knowledge with OR 4.353 .

\section{REFERENCES}

[1] MoH RI, "Indonesia Health Profile 2013," Jakarta, MoH RI, 2014.

[2] Mirza N. M., et al., "Risk Factors for Diarrheal Duration," American Journal of Epidemiology, vol/issue: 146(9), pp. 776-85, 1997.

[3] Salim H., et al., "Risk Factors of Rotavirus Diarrhea in Hospitalized Children in Sanglah Hospital, Denpasar: A Cohort Study Prospective," BMC Gastroenterology, vol. 14, pp. 54-9, 2014.

[4] Center for Data and Surveilans of Health, "Diarrhea Situation in Indonesia," Window Data and Information Health Bulletin, vol/issue: 2(2), pp. 1-18, 2011.

[5] Agtini M. D., "Morbidity and Mortality Diarrhea in Todlers in Indonesia from 2000 to 2007," Window Data and Information Health Bulletin, vol/issue: 2(2), pp. 25-32, 2011.

[6] Kupang City Health Office, "Health Profile of Kupang City 2011," Kupang, Kupang City Health Office, 2012.

[7] Kupang City Health Office, "Health Profile of Kupang City 2012," Kupang, Kupang City Health Office, 2013.

[8] Kupang City Health Office, "Health Profile of Kupang City 2013," Kupang, Kupang City Health Office, 2014.

[9] Control SoDaR, "Diarrhea Control in Indonesia," Window Data and Information Health Bulletin, vol/issue: 2(2), pp. 19-24, 2011.

[10] Pane E., "Family Behavioral Influence on the Use of Toilets," Kesmas Journal, vol/issue: 3(5), pp. 229-34, 2009.

[11] Notoatmodjo S., "Public Health Sciences," Jakarta, Rineka Cipta, 2003.

[12] Evayanti N. K. E., et al., "Factors Associated with Diarhea Incidence in Toddlers Treatment Agency to Tabanan General Hospital," Journal of Environmental Health, vol/issue: 4(2), pp. 134-9, 2014

[13] Hikmah F. A., "Relationship between Knowledge of Mother with Diarrhea Incidence in Toddlers Age 2-5 Years in PHC Karanganyar,” Surakarta, UMS, 2012.

[14] Wardoyo F. S., "Relationship between Knowledge of Mother about Diarrhea and Latrine Condition with Diarrhea Incidence on Childhood in Blimbing Sambirejo Village, Sragen District," Semarang, UNNESA, 2010.

[15] Hidayat A. A., "Introduction of Pediatrics for Education," Jakarta, Salemba Medika, 2008.

[16] Rahmawati F. A., "Latrine Ownership Relationship with the Incidence of Diarrhea in Toddlers in Sukoharjo District," Surakarta, UMS, 2012.

[17] Umiati, "The Relationship Between the Environmental Sanitation with Diarrhea Incidence in Toddlers at Nogosari PHC, Boyolali," Surakarta, UMS, 2010.

[18] Adisasmito W., "Risk Factors of Diarrhea in Infants and Toddlers in Indonesia: Systematic Teview of Public Health Academic Research," Makara, vol/issue: 11(1), pp. 1-10, 2007.

[19] Entjang I., "Public Health Sciences," Bandung, PT Citra Aditya Bakti, 2000.

[20] Darsana I. N., et al., "Factors Associated with Ownership Family Latrines in the Village Jehem Tembuku District of Bangli," Journal of Environmental Health, vol/issue: 4(2), pp. 124-33, 2014.

[21] Sander M. A., "Socio - Cultural Factors Relationship with Diarrhea Incidence in the Candinegoro Wonoayu Village," Sidoarjo Subdistrict Medical Journal, vol/issue: 2(2), pp. 163-93, 2005.

[22] Abdullah A. Z., et al., "Faktor Risiko Diare Shigellosis pada Anak Balita," Jurnal Kesehatan Masyarakat Nasional, vol/issue: 7(1), pp. 16-21, 2012.

[23] Ehlayel M. S., "Protective Effect of Breastfeeding on Diarrhea among Children in a Rapidly Growing Newly Developed Society," The Turkish Journal of Pediatrics, vol/issue: 51(6), pp. 527-33, 2009.

[24] Lamberti L. M., et al., "Breastfeeding and the Risk for Diarrhoea Morbidity and Mortality," BMC Public Health, vol/issue: 11(3), pp. 15, 2011.

[25] Molbak K., et al., "Risk Factors for Diarrehal Diseases Incidence in Early Childhood: A Community Cohort Study from Guinea-Bissau," American Journal of Epidemiology, vol/issue: 146(3), pp. 273-82, 1997. 
[26] Horta B. L. \& Victoria C., "Short-term Effects of Breastfeeding: A Systematic Review on the Benefits of Breasfeeding on Diarrhea and Pneumonia Mortality," Geneva, WHO, 2013.

[27] Diouf K., et al., "Diarrhoea Prevalence in Children Under Five Years of Age in Rural Burundi: an Assesment of Social and Behavioural Factors at the Household Level," Global Health Action, vol. 7, 2014. 